\title{
FACTORS INFLUENCING THE IMPOSITION OF A CHARGE ON THE ENTRANCE TO THE INTERPRETIVE TRAILS IN THE LARGE PROTECTED AREAS
}

\author{
Josef Navrátil, Kamil Pícha
}

Received: February 26, 2013

\begin{abstract}
NAVRÁTIL JOSEF PÍCHA KAMIL: Factors influencing the imposition of a charge on the entrance to the interpretive trails in the large protected areas. Acta Universitatis Agriculturae et Silviculturae Mendelianae Brunensis, 2013, LXI, No. 4, pp. 1041-1049

The aim of this paper is to assess the relation between the character of the interpretive trail and the imposition of a charge on the entrance. This was done using the discrete choice experiment that involves eight attributes, seven of which are with three levels: the overall character of the trail, the way that the route signs are used in the terrain, the ways of providing information, the length of the trail, the way of the routing, the focus of the trail, and the price of the entrance. There is also one with two levels that involves the existence of the places for rest. The fractional factorial design was used (the orthogonal main effects plan) and the Multinomial Logit Model was used in analyzing the data. The 2,830 choices were done by random sampled visitors from eight tourist locations in the Tourist Regions of the Šumava Mts. and South Bohemia during the summer season 2012. The impact of the character of the trail was especially detected in the model. Except for that, the equipment of the trail and its length have had the fundamental impact on the choice of the trail as well. Those longer and worse equipped trails have a significantly lower degree of utility for the respondents. What is quite surprising is that the respondents refused the ecotourism elements of the interpretive trails, such as the possibility of going through the trail on horseback or the accompaniment of an expert who would provide some comments, as it is common to do this at historical attractions within those sightseeing paths.
\end{abstract}

interpretive trail, tourism, price, entrance fee, South Bohemia

The large protected nature and landscape areas represent one of the basic sources of tourism in the Czech Republic (Vystoupil, Šauer, Holešinská, Kunc, Seidenglanz \& Tonev, 2011) as well as elsewhere in the world (Ritchie \& Crouch, 2003). The strain of the tourism on such an environment is enormous and the result of that is the damage of the environment of the respective area, which constitutes the act of limiting the entrance or even a complete closure of an area for visitors. However, the justified restrictive measures have met some opposition from some stakeholder groups that have emphasized economic benefits of tourism. These groups are gaining an important support in the Czech Republic from the public for instance, as the above mentioned conflict of interest has taken part in those areas that are, at the same time, economically weak (Hrabánková \& Boháčková, 2007) and that are faced with a wide scale of further social and economic problems (Martinát, Frantál, Klusáček, \& Klapka, 2009; Foret \& Klusáček, 2011). Conflicts between tourism and the conservation of nature have become an important political issue (Novinky, 2010). With regard to the fact that the national park visitation and nature-based tourism are the critical components for fostering the support for national parks and the conservation of the biological and cultural heritage contained within 
them (Bushell, Staiff, \& Eagles, 2007), it is necessary to find a solution to this situation, so that the requirements of both tourism and the protection of nature and the landscape are to be satisfied (von Hirnschall et al., 2012). One of the possible solutions seems to be the support of those types of tourism, which are exempt from the negative influence on the environment and which have a basic economic contribution to both the visited area and the local communities (Hall \& Lew, 2009). Particularly, the activities of ecotourism (Epler Wood, 2002), sustainable tourism (Weaver, 2006; Győri, 2010) and generally environment-friendly tourism (Holden, 2008) belong to such types of tourism as mentioned in previous sentence.

Several support tools exist for the environmental education, but the one that is used the most is an interpretive trail (Cecioni, 2005). Interpretive trails are defined as those trails that are often being specifically designed to provide natural or cultural interpretation of an area. These types of trails include marking, brochures or other kinds of written information to provide this interpretation (DCR, 2012). They have various subject orientations (Rogerson, 2007). The most common are the thematic interpretive trails of natural or cultural heritage that are marked out in the terrain in the national parks and other protected areas (Leung, 2012) and their creation is developed particularly in relation to the increase of the importance of geotourism nowadays (Pereira, Ferreira, \& Rocha, 2012; Zgłobicki, Kotodyńska-Gavvrysiak, Gawrysiak, \& Pawłowski, 2012) and also of the study within restoration ecology as well (Dantzler, Gering, Straka, \& Yarrow, 2008; Koski, 2005). The main forms of this movement in the case of those trails are hiking or trekking, bicycle touring or hippo tourism (Hughes \& Morrison-Saunders, 2002). The routing itself corresponds to the potential, the attractiveness and the protectionist importance of the respective territory (Navrátil, Pícha, \& Martinát, 2012).

Interpretive trails especially increase the level of the visitors' awareness about the value of the area where they are at the moment (Ferreira, 1998). The substance of the potential benefit of tourism to sustainability is just in the educational aspect of the visits to the naturally or culturally interesting locations and thus in their positioning in the visitors' awareness (Epler Wood, 2002). So the interpretive nature trails constitute an important component of the support to both the sustainable development of tourism (Topole, 2009) and the inhabitants' environmental awareness (Clark, 1997; Prah \& Kolnik, 2007). Although this research showed that the information given at the interpretive trails are adapted to the requirements of the contract owner (Braithwaite \& Leiper, 2010) and the consequent behaviour of the visitors does not show any significant changes towards the compliance with the environmental friendliness in the longer-term horizon (Hughes, 2013), their importance regarding environmental awareness is indisputable (Angelini,
Simião Ferreira, Santiago do Carmo Araújo, \& Rosa Carvalho, 2011).

Although the aim of creating the interpretive trails is the long-term increase of the visitors' environmental awareness, the statement is as follows: with regard to the fact that building of the interpretive trails consumes a lot of money, a much larger number of the administrators of these trails is inclined towards the imposition of an entrance fee. The main reason cited is the procurement of the means which are usable for reconstruction of the environment that has been disrupted by these visits. Though in contrast to the neighbouring countries, and since this practice still is not very common in the Czech Republic, we have set up the assessment of the relation between the character of the interpretive trail and the imposition of an entrance fee or entrance charge to be the objective of this paper.

\section{METHODS}

The achievement of the objective set above was done using the Discrete Choice Modeling (DCM). The employment of this method does not belong to the most common ones in tourism (Kelly, Haider, Williams \& Eglund, 2007); however, its strength is in the low load of the respondents and in the possibility to identify the value of the particular observed attributes. It is therefore often employed in those cases where the objective is, next to the assessment of the importance of particular attributes. It also assesses their relative price, if they become a part of the offer (Greene, 2002). The DCM aims to evaluate the various managerial and marketing initiatives that would assist in giving information regarding policymaking that is based on the respondents' choice patterns (Apostolakis \& Jafry, 2005b). The discrete choice framework is based on the stated choice preferences that require the respondents to choose each of which is characterized by multiple product attributes, among the multiple attributes (Apostolakis \& Jafry, 2005a). The DCM is based on the Random Utility Maximization theory: each individual consumer has generated his or her market behaviour by the maximization of his or her preferences. These preferences are not necessarily observable by the researcher for a particular good. However, in the DCM, this variation between what the respondent chooses and what the researcher records could be explained by a random element as a component part of the respondent utility function for each alternative (Apostolakis \& Jafry, 2005a, 2005b). This random element could be estimated, as it does vary among the respondents; (for detailed see Henshner, Rose, \& Greene, 2005). Then its use has its advantages when comparing it to the revealed preferences (RP) approach (Bateman et al., 2002).

\section{Product atribute selection}

As already mentioned above, the DCM is technically based on that principle, where the 
respondent chooses from the presented choice sets. These sets contain particular choices that are constituted by particular levels of each studied attribute. The key point for creating the meaningful model is exactly the choice of the attributes and their levels. The product attributes, as well as their levels, were based on previous research. That research employed the revealed preferences regarding the attributes of interpretive trails (Navrátil, Knotek, Švec, Pícha, \& Navrátilová, 2011) and the selected literature review (EETAP, 2002; Leung, 2012; DCR, 2012). The results pointed out rather differentiated preferences of the partial elements of the interpretive trails. The following seven issues especially arise: the overall character of the trail, the way of that the route signs are used in the terrain, the ways of providing the information, the length of the trail, the way of the routing, the existence of the places for rest and the focus of the trail. The problem of the entrance price was matched as the eighth one.

Among the preferences revealed by the research, the most important attribute seems to be the overall character of the trail, which is given, above all, by the type of the trail surface and the permeability of the terrain. Then we can distinguish three main types: first of all, those types having the characteristics for hiking and, secondly, those having the particular characteristics for bicycle touring. The third type was noticed to be especially important for women: those trails with the characteristic of hippo trails. These three types thus constitute the main diversity of the offer of the interpretive trails, where the type of the characteristics for hikers is the fundamental type and also the most widely spread one in the offer of the interpretive trails in the Czech Republic. So this type represents the basic level of what is being offered. With regards to the significant part of the bicycle tourists who decidedly prefer bicycle touring to hiking as choice of outdoor activities, it is possible to expect a positive impact of the increasing in the offer of interpretive trails with bicycle touring characteristics. However, their offer is not as wide at the moment (Navrátil, Pícha, \& Martinát, 2012). Hippo tourism represents a dynamically developing phenomenon in the Czech Republic (Hollý, 2003), which is demanded (Navrátil et al., 2011), but the degree of the participation of tourists is still relatively low. The offer of the interpretive trails is likewise strongly limited. Therefore it is possible to expect a mixed effect from the increase of the offer.

According to the RP study, the marking of the interpretive trails in the terrain seems to be another important attribute of the interpretive trail, the perception of which differs particularly according to the visitor's experience. However, there is also the impact of gender. The basic level in the offer of these nature trails in the Czech Republic is represented by the marking by special tourist marks for interpretive trails. With regard to the development of new technologies, we can expect that the nature trails without field marking could be also developed in the future. Nowadays, the negative impact of the non-existence of the marking on the choice of the interpretive trails can be expected. Between the classic field marking of the interpretive trails and the trails without any field marking, there is the marking of the crossroads, which is typical for trails intended for bicycle touring. On the other hand, this marking represents a reduction in the standard of the offer compared to the usual marking of the interpretive trail. Then the impact is impossible to estimate.

The third attribute of the interpretive trails is the way of providing the information that belongs to the most important elements which are different from the interpretive trails from the basic tourist field marking of these routes and to which the biggest attention is paid to in literature (Pereira, Ferreira, \& Rocha, 2012). The basic level in the offer is constituted by the information boards (DCR, 2012). The other developing method of providing information is the electronic way (DCR, 2012); however this one is only currently attractive based on the demand of the youngest age groups. The replacement of the information boards by the electronic means of the transfer of information is then possible to consider as the reduction in the standard and a negative impact on the option of a choice as well. The most long-term experience obtained in field is from the expert from the point of view of the educational value of the interpretive trails. The offer of the interpretive trails is very low in the Czech Republic and it is concentrated into the large-area protected territories of nature. The attendance of these trails as well as the interest in such trails is very low within the current tourism demand; it is then possible to expect a negative impact of this offer on the selection of the choice.

The fourth attribute is the length of the trail. The major number of these trails has the length from 5 to $15 \mathrm{~km}$. Thus we can consider this length to be the basic level. Other levels are represented by those trails with the length of less than $5 \mathrm{~km}$ and the trails longer than $15 \mathrm{~km}$. The expected impact in both cases is negative.

The fifth attribute is the way of routing. The basic level begins and finishes in different points, which is the basic way of the routing of both the general tourist trails and the interpretive trails. We can often encounter the ring circuit, where the point of departure and terminal points are spatially identical, particularly in the case of those trails with only one important dominant characteristic. In the research area, it concerns usually the rather shorter trails designated for hikers and, on the contrary, the long trails for bicycle touring as well (Navrátil, Pícha, \& Martinát, 2012).

In order to support the repetition of a visit to the same destination, it is possible to create even the variant routing. It is possible to suppose a positive impact of the offer of those possibilities on the option of choice in both cases.

The focus of the trail was identified as the sixth attribute. The basic level is represented by the general focus of the trail as that focus was in the 
revealed preferences experiment (Navrátil et al., 2011). It is decidedly the most preferred variant of the focus. The general focus is also the most widespread in the surveyed area (Navrátil, Pícha, \& Martinát, 2012). It exists yet an important part of the market demand for tourism in the surveyed area, whose concrete goal is the nature of the territory or its culture (Navrátil, Pícha, \& Navrátilová, 2012). That is why the interpretive trails being specialized on history or nature were chosen as being potentially suitable for creation the supply. The support of the option of choices comprising these variants is expected, in both cases.

The seventh attribute is the equipment of the trail by the specially adjusted rest areas. The big part of the particularly older interpretive trails was built without any infrastructure (the base level). The offer of these trails was then tested by the model as the equipment of the trail by the rest areas belongs, next to the way of providing with information, to the main equipment of the interpretive trails (DCR, 2012).

The eighth attribute was added to the previous seven and it is the price of the chargeable entrance into the trail. The price of $25 \mathrm{CZK}$ (approx. 1 EUR) was set as a base level and it corresponds to the standard price of the entrance in neighbouring countries. It also corresponds to the parking fee in the Czech Republic (divided among passengers) when visiting the important historical monument in the surveyed area. On the other level, it was opted for the price of $75 \mathrm{CZK}$ (approx. 3 EUR), which corresponds with the average entrance fee into the historical attractions. Concerning the third level, the mean of the two previous prices was chosen: $50 \mathrm{CZK}$ (approx. 2 EUR), which is related with the variant pricing between the basic entrance fee and usual entrance fee at the historical attractions.

\section{Discrete choice experiment}

It results from the above mentioned, that the discrete choice experiment involves eight attributes, seven of which are with three levels and one with two levels (summarized in Tab. I). With regard to such high number of alternatives, the fractional factorial design was used (orthogonal main effects plan), when looking for the way of the generating alternatives. The plan mentioned by Jugulum and Saul (2010) was adopted and choice sets were created using the procedure proposed in Street, Burgess and Louviere (2005). This procedure allowed the use of the Multinomial Logit Model when analyzing the data. 18 pairwise choice sets were created this way. Two random choice sets were presented to each respondent. The number of questionnaires depended on the meeting the requirement, that each choice is opted for at least 50 times (Henshner, Rose, \& Greene, 2005). 1,600 interviews comprising 2830 choices were done. The field study was done at eight tourist locations in the Tourist Regions of

I: Attributes and attributes' level used in DCM

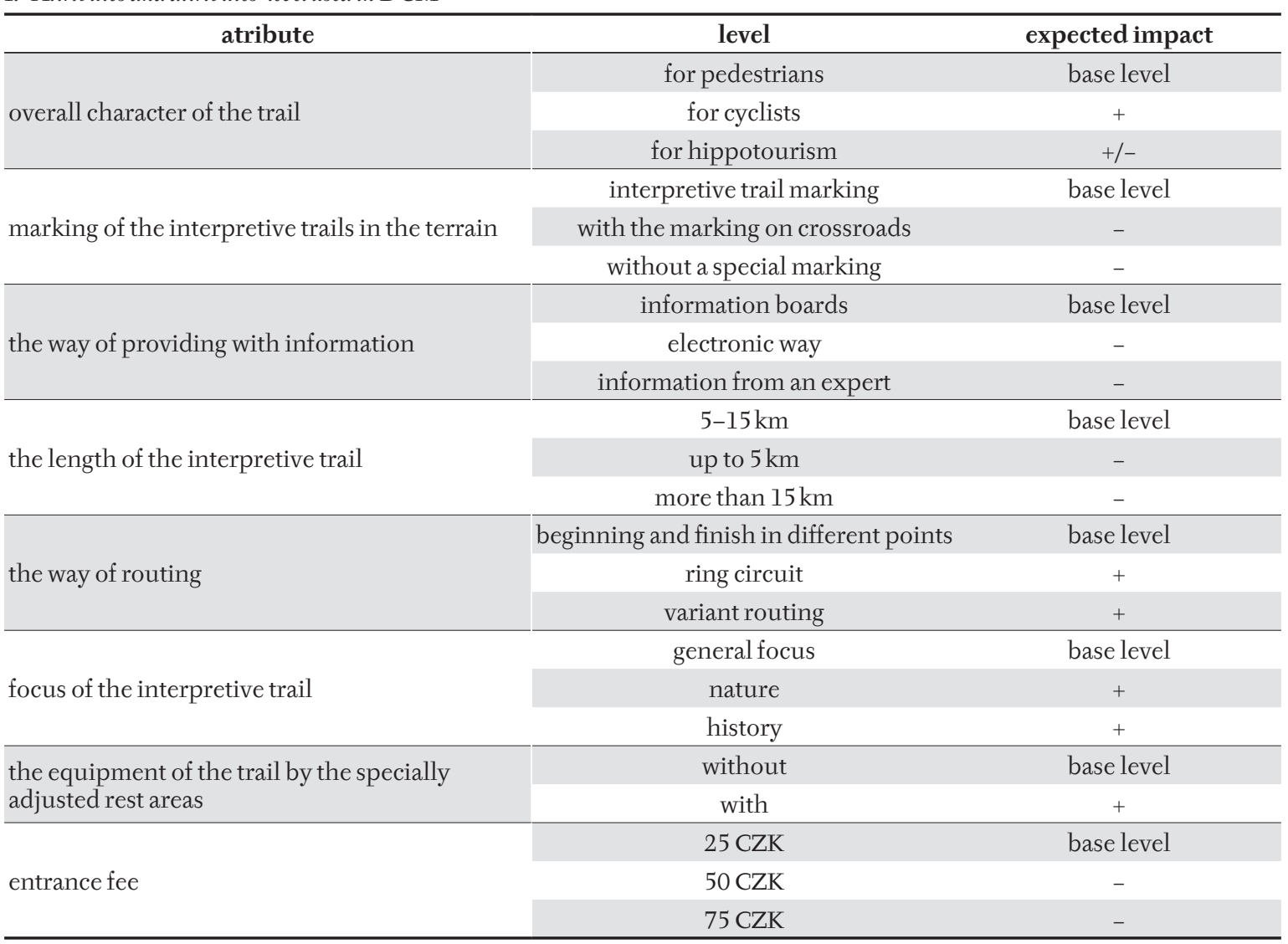


the Šumava Mts. and South Bohemia (Cetkovský, Klusáček, Martinát, \& Zapletalová, 2007), as study areas during the summer season 2012. 200 questionnaires were collected at each location. The structured interviews were done by trained interviewers.

The answers of respondents were digitized: all of the categorical attributes were effect coded and the numerical attribute (the entrance fee) was linear coded (Henshner, Rose, \& Greene, 2005). The maximum likely procedure of the Multinomial Logit Model using the NLOGIT 4.0 software (Greene, 2002) was performed to estimate the parameters of the choice model. As the part of the experiments were the linear levels of the price of entrance into the interpretive trail, it was possible to calculate also the marginal willingness-to-pay (Greene, 2002), which means the amount of money individuals are willing to forfeit in order to obtain some benefit from the undertaking of some specific action or task (Henshner, Rose, \& Greene, 2005). It can be estimated by the ratio of coefficients represented by the level of the product attribute over the price coefficient (Apostolakis \& Jafry, 2005a).

\section{RESULTS AND DISCUSSION}

The resulting model (Tab. II) shows the value of adjusted pseudo $\mathrm{R}^{2}=0.12$, which is not excellent. On the other hand, its value correspond to the approx $30 \%$ of the explained variability of data according to the linear R² (Henshner, Rose, \& Greene, 2005). This value is usually accepted in scientific literature (e.g. Kelly et al., 2007). Validity of the model is backed up by the low number of iteration (5) during its construction (Henshner, Rose, \& Greene, 2005).
The overall character of an interpretive trail is of the highest importance for the choice to visit it. The decidedly preferred type is that being designated for going through the interpretive trail by bicycle. On the contrary, the adjustments allowing tourists to go through when riding on horseback constitutes the non-option of such trails for a visit. The first finding is not surprising with regard to the important part of tourists in the surveyed area, who prefer a bicycle to other forms of movement in the visited area (Navrátil, Pícha, \& Navrátilová, 2012). The impact of bicycle tourism as an important phenomenon of the long-stay tourism in the surveyed area on the observed preferences was detected also in previous researches (Navrátil et al., 2011). The possibility of going through an interpretive trail when riding a horse belonged in our RP study to the rarely opted possibilities and it was particularly chosen by women (Navrátil et al., 2011). When evaluating the whole of answers in the surveyed sample, this possibility has a decided and very strong impact on the non-option of the offered variant.

The respondents were indifferent to the different types of marking of the interpretive trails in the terrain. The coefficients are negative in the case of the non-existence of any marking but also in the case of the marking on crossroads; however, they are not statistically significant. Also the levels of the way of providing with information have the expected sign, where the providing with information belongs to the most important elements differentiating interpretive trails from the basic tourist marking of the routes. In the case of providing information by the expert, the coefficient is negative and very near to the significant impact on the decision-making of the respondent. On the contrary, the possibility of

II: Results of DCM

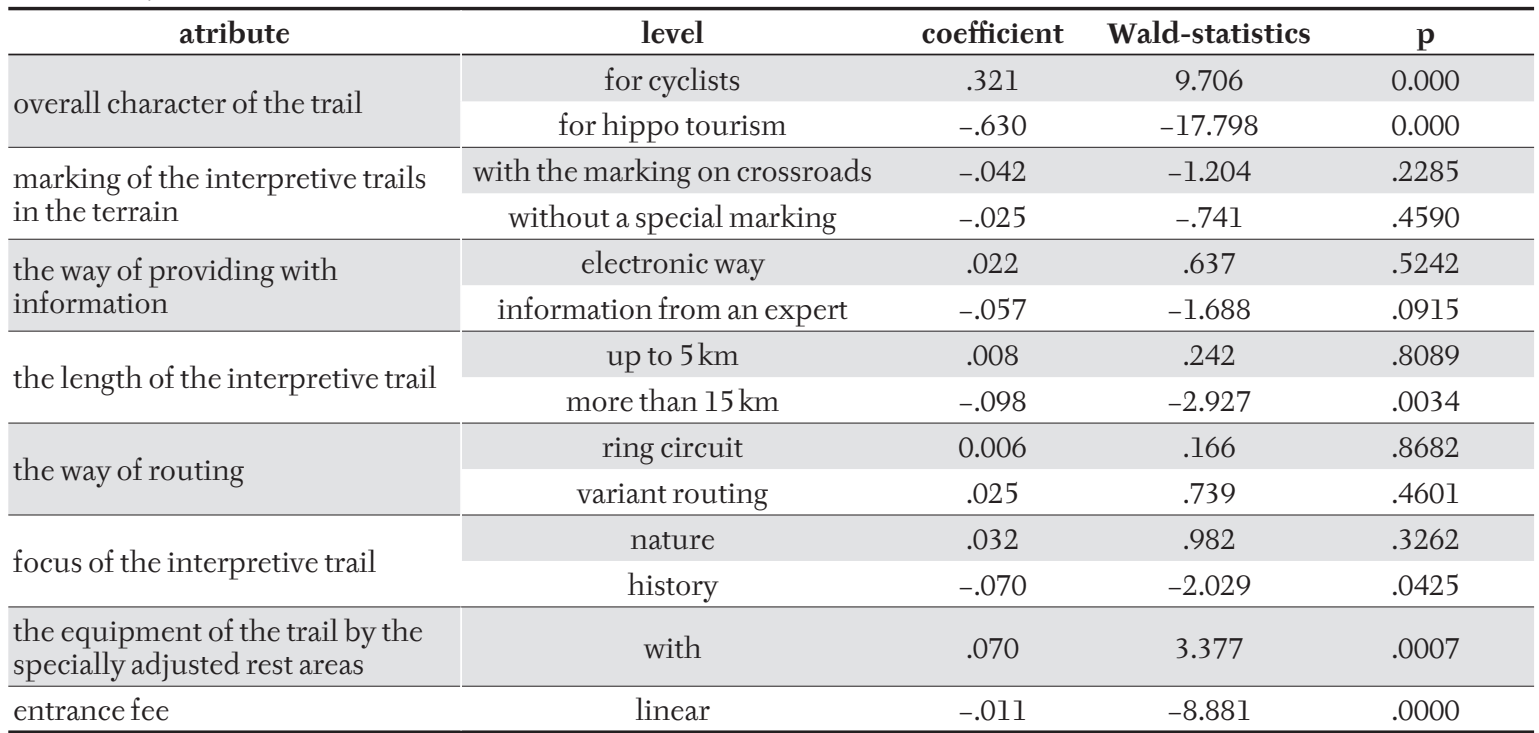

Coefficient = weight or parameter associated with attribute in regression model

Wald-statistics = statistical test testing whether a variable contributes to explaining the choice response $\mathrm{p}=$ significance level of Wald-statistics 
obtaining information through some of electronic services has the coefficient with a positive value.

On the other hand, the impact of the length of the route on the choice of a trail was proven, it was negative for length exceeding $15 \mathrm{~km}$. The respondents are completely indifferent towards the shorter lengths. So those longer trails discourage visitors. Also the way of routing is related to the length of the trail. The respondents were quite surprisingly indifferent to both variants.

In the case of the specialized focus of the trail, we did not successfully proved the impact of natural focus of trails on the choice of the interpretive trail. It has a positive coefficient. In contrast, the historically oriented trails have a significantly lower limit to be chosen when opting for a nature trail to attend. This finding could be in contradiction to the importance of the cognition of history for visitors of the surveyed territory (Navrátil, Pícha, \& Hřebcová, 2010; Navrátil, Pícha, \& Navrátilová, 2012). However, as it was already proved, this "interest" does not correspond with the existing knowledge and with the intent to learn about something (Navrátil et al., 2011).

With regards to the fact that the interpretive trails have a different character from the classic field marking (DCR, 2012), they used to be equipped also by the rest areas, particularly in the places with an information board. The results of research show that the provision of this service has an impact when choosing an interpretive trail to attend.

As already mentioned above, the imposition of a charge on the entrance into the interpretive trail is not usual in the Czech Republic. However, it is not unusual in the neighbouring countries and that is why the impact of the price on the choice of an interpretive trail to attend was also measured. The amount of the entrance fee decidedly influences the willingness to go through the trail: the higher is the price, the lower is the willingness to attend the interpretive trail. This is an expected phenomenon and a common finding in this type of research
(Apostolakis \& Jafry, 2005a; Kelly et al., 2007). With regard to the fact that the impact of the price was put into our research, we were able to determine for each studied variable even the marginal willingnessto-pay (Tab. III). At this point, it is worth to comment particularly the reduce of tourists' derived utility in case of the ecotourism activities, to which belong the riding through an interpretive trail on horse and/or when being accompanied by an expert. The reduction of the tourists' derived utility is detected also in case of a lower level of equipment of a trail, be it by the marking or the rest areas. The impact on the tourists' derived utility is minimal in case of the variant layout of the routes. The fundamental given impact is then the impact of the overall character of the trail. A huge interest in bicycle touring along the interpretive trails was confirmed, which corresponds with a high part of bike tourists on the visitation rate of the destination area (Navrátil, Pícha, \& Navrátilová, 2012). The other values of the marginal-willingness-to-pay are not proportionally lower than the above mentioned ones.

\section{CONCLUSION}

The discrete choice experiment was employed in order to assess the imposition of a charge on the entrance into the interpretive trails in the Czech Republic. The impact of the character of the trail was especially detected in the model. With that exception, the equipment of the trail and its length as well has the fundamental impact on the choice of the trail. Those longer and worse equipped trails have a significantly lower degree of utility for the respondents. What was quite surprising is that the respondents refused the ecotourism elements of the interpretive trails, such as the possibility of going through the trail on horseback or the accompaniment of an expert providing commentary as it is common at historical attractions within their sightseeing paths.

III: Marginal willingness to pay (MWTP) in CZK

\begin{tabular}{llc}
\hline \multicolumn{1}{c}{ atribute } & \multicolumn{1}{c}{ level } & MWTP \\
\hline \multirow{2}{*}{ overall character of the trail } & for cyclists & 32.12 \\
\hline \multirow{2}{*}{ signage of the interpretive trails in the terrain } & for hippotourism & -59.05 \\
\hline \multirow{2}{*}{ the way of providing with information } & with the marking on crossroads & -3.89 \\
\cline { 2 - 3 } the length of the interpretive trail & without a special marking & -2.32 \\
\hline \multirow{2}{*}{ the way of routing } & electronic way & 2.38 \\
\hline \multirow{2}{*}{ focus of the interpretive trail } & information from an expert & -5.35 \\
\hline the equipment of the trail by the specially adjusted rest areas & up to 5 km & 0.78 \\
\hline
\end{tabular}


The interest in visiting an interpretive trail is inversely related to the amount of the entrance fee. So the fee could rather be used as a tool of decrease of the negative impact of the visitors on the natural environment than a tool to get money for the maintenance of an interpretive trail.

It also emerged that the trails are assessed differently by different tourism participants. So the approach to the imposition of a charge should be special for particular types of interpretive trails, as their character fundamentally differs one from another and then it influences the willingness to pay for the entrance into these trails. Thus the interpretive trail' creators or keepers should thus consider the focus of the trail and typical tourist participants when setting an entrance fee.

\section{SUMMARY}

Although the aim of creating the interpretive trails is the long-term increasing of the visitors' environmental awareness, the statement is as follows: with regard to the fact, that building of the interpretive trails is a very money consuming work, a greater and greater number of the administrators of these trails is inclined to the imposition of a charge on the entrance. In contrast, since this practice is done in the neighbouring countries, not very common in the Czech Republic, we have set up the assessment of the relation between the character of the interpretive trail and the imposition of a charge on the entrance to be the objective of this paper. The achieving of the set objective was done using the Discrete Choice Modeling. The discrete choice experiment involves eight attributes, seven of which are with three levels: the overall character of the trail, the way that the route signs are used in the terrain, the ways of providing information, the length of the trail, the way of the routing, the focus of the trail, and the price of the entrance. With regard to such a high number of alternatives, the fractional factorial design was used (the orthogonal main effects plan) and the Multinomial Logit Model when analyzing the data was used. 2,830 choices were done by random sampled visitors of eight tourist locations in the Tourist Regions of the Šumava Mts. and South Bohemia during the summer season 2012. The impact of the character of the trail was especially detected in the model. Except for that, the equipment of the trail and its length as well has the fundamental impact on the choice of the trail. Those longer and worse equipped trails have significantly lower degree of utility for the respondents. It is quite surprising is that the respondents refused the ecotourism elements of the interpretive trails, such as the possibility of going through the trail on horseback (coefficient -0.630; Wald-statistics -17.798), or the accompaniment of an expert providing a commentary, which is common at historical attractions within their sightseeing paths (coefficient-0.057; Wald-statistics -1.688). With regard to the fact that the impact of the price was put into our research, we were able to determine for each studied variable the marginal willingness-to-pay.

\section{Acknowledgement}

The survey as well as the preparation of this paper was supported from the Czech Science Foundation - GACR P404/12/0334 'Factors of visitors' relation to the ambience of attractions in vulnerable areas.'

\section{REFERENCES}

ANGELINI, R., SIMIÃO FERREIRA, J., SANTIAGO DOCARMO ARAÚJO, C., and ROSA CARVALHO, A., 2011: Effect of outdoor and laboratorial environment science activities on middle school students understanding on conservation. Natureza a Conservacao, 9, 1: 93-98. ISSN 1679-0073.

APOSTOLAKIS, A. and JAFFRY, S., 2005a: A choice modeling application for Greek heritage attractions. Journal of Travel Research, 43, 3: 309-318. ISSN 0047-2875.

APOSTOLAKIS, A. and JAFFRY, S., 2005b: Stated preferences for two Cretan heritage attractions. Annals of Torism Research, 32, 4: 985-1005. ISSN 0160-7383.

BATEMAN, I. J., CARSON, R. T., DAY, B., HANEMANN, M., HANLEY, N., HETT, T. JONES-LEE, M. et al., 2002: Economic valuation with stated preference techniques. 1st ed. Cheltenham:
Edward Elgar Publishing Limited, 458 p. ISBN 1840649194.

BRAITHWAITE, R. W. and LEIPER, N., 2010: Contests on the River Kwai: how a wartime tragedy became a recreational, commercial and nationalistic plaything. Current Issues in Tourism, 13, 4: 311-332. ISSN 1368-3500.

BUSHELL, R., STAIFF, R., and EAGLES, P. F. J., 2007: Tourism and protected areas: Benefits beyond boundaries. In: BUSHELL, R. and EAGLES, P. F. J. (eds.), Tourism and protected areas: Benefits beyond boundaries, The Vth IUCN World Parks Congress. Wallingford: CABI. pp. 1-11. ISBN 978-0-8519022-4.

CECIONI, E., 2005: Environmental education and geography of complexity. International Research in Geographical and Environmental Education, 14, 4: 277294. ISSN 1038-2046.

CETKOVSKÝ, S., KLUSÁČEK, P., MARTINÁT, S. and ZAPLETALOVÁ, J., 2007: Some aspects 
of cross-border cooperation in Euroregions of the Czech Republic: An example of the Šumava Region. Moravian Geographical Reports, 15, 1: 43-55. ISSN 1210-8812.

CLARK, G., 1997: The educational value of the rural trail: a short walk in the Lancashire countryside. Journal of Geography in Higher Education, 21, 3: 349362. ISSN 0309-8265.

DANTZLER, D. W., GERING, L. R., STRAKA, T. J. and YARROW, G. K., 2008: Creating a destination for tourism, recreation, and education on an active solid waste landfill site. Natural Areas Journal, 28, 4: 410-413. ISSN 0885-8608.

DCR, 2012: Trails guidelines and best practices manual. [online] URL: <http://www.mass.gov/dcr/ stewardship/greenway/docs/DCR_guidelines. pdf $>$ [2012-02-01].

EPLER WOOD, M., 2002: Ecotourism: Principles, practices and policies for sustainability. 1st ed. UNEP: Nairobi, 64 p. ISBN 92-807-2064-3.

EETAP, 2002: Educational use of nature trails. EETAP Resource Library, 105. [online] URL: <http://eelink. net/eetap/infol05.PDF $>$ [cit. 2010-12-30].

FERREIRA, G., 1998: Environmental education through hiking: A qualitative investigation. Environmental Education Research, 4, 2: 177-183. ISSN 1350-4622.

FORET,M.and KLUSÁČEK,P., 2011:Theimportance of the partnership and cooperation in the regional development exampled on Znojmo region. Acta Universitatis Agriculturae et Silviculturae Mendelianae Brunensis, 59, 4: 79-85. ISSN 1211-8516.

GREENE, W. H., 2007: NLOGIT version 4.0. Reference guide. Plainview: Econometric software, Inc.

GYÖRI, E., 2010:The Establishment of the Principles of Sustainable Tourism in the Balaton Region. Deturope, 2, 1: 46-64. ISSN 1821-2506.

HALL, C. M. and LEW, A. A., 2009: Understanding and managing tourism impacts: An integrated approach. 1st ed. London and New York: Routledge, 365 p. ISBN 978-0-415-77133-7.

HENSHNER, D. A., ROSE, J. M., and GREENE, W. H. 2005: Applied choice analysis: A primer. 1st ed. Cambridge: Camridge University Press, 717 p. ISBN 978-0-251-60577-9

HOLDEN, A., 2008: Environment and Tourism. 2nd ed. London and New Yourk: Routledge, 274 p. ISBN 978-0-415-39955-5.

HOLLÝ, K., 2003: Jezdecká turistika. 1. vyd. Ostrava: Montanex, a. s., 109 s. ISBN 80-7225-104-X.

HRABÁNKOVÁ, M. and BOHÁČKOVÁ, I., 2007: Conditions of sustainable development in the Czech Republic in compliance with the recommendation of the European Commission - Scientific information. Agricultural Economics Czech, 53, 6: 285-289. ISSN 0139-570X.

HUGHES, K., 2013: Measuring the impact of viewing wildlife: do positive intentions equate to longterm changes in conservation behaviour? Journal of Sustainable Tourism, 21, 1: 42-59. ISSN 0966-9582.

HUGHES, M. and MORRISON-SAUNDERS, A., 2002: Impact of trail-side interpretive signs on visitor knowledge. Journal of Ecotourism, 1, 2-3:122132. ISSN 1472-4049.

JUGULUM, R. and SAUL, P., 2010: Design for Lean Six Sigma: A holistic approach to design and innovation. 1st ed. Hoboken: John Wiley \& Sons, Inc. 320 p. ISBN 9780470007518.

KELLY, J., HAIDER, W., WILLIAMS, P. W., and EGLUND, K., 2007: Stated preferences of tourists for eco-efficient destination planning options. Tourism Management, 28, 2: 377-390. ISSN 02615177

KOSKI, A.E., 2005: Pond rehabilitation and establishment of a site-based environmental education curriculum. 22nd American Society of Mining and Reclamation Annual National Conference. Brackenridge: American Society of Mining and Reclamation. 2005, 2, pp. 645-653. ISBN 978-162276-086-2.

LEUNG, Y.-F., 2012: Recreation ecology research in East Asia's protected areas: Redefining impacts? Journal for Nature Conservation, 20, 6: 349-356. ISSN 1617-1381.

MARTINÁT, S., FRANTÁL, B., KLUSÁČEK, P. and KLAPKA, P., 2009: New rural spaces: Conflicts, opportunities and challenges. Moravian Geographical Reports, 17, 4: 44-45. ISSN 1210-8812.

NAVRÁTIL, J., KNOTEK, J., ŠVEC, R., PÍCHA, K., a NAVRÁTILOVÁ, J., 2011: Návštěvnické preference naučných stezek ve velkoplošně chráněných územích. Czech Hospitality and Tourism Papers, 8, 14: 3-16. ISSN 1801-1535.

NAVRÁTIL, J., PÍCHA, K. and HŘEBCOVÁ, J., 2010: The importance of historical monuments for domestic tourists: The case of South-western Bohemia (Czech Republic). Moravian Geographical Reports, 18, 1: 45-61. ISSN 1210-8812.

NAVRÁTIL, J., PÍCHA, K. and MARTINÁT, S., 2012: Spatial differentiation of the interpretive nature trails in the large-area protected natural territories. Acta Universitatis Palackianae Olomucensis Facultas Rerum Naturalium, Geographica, 43, 2: 101-115. ISSN 1212-2157.

NAVRÁTIL, J.,_PÍCHA, K. and NAVRÁTILOVÁ, J., 2012: Satisfaction with visit to tourism attractions. Tourism, 60, 4: 411-430. ISSN 1332-7461.

NOVINKY, 2010: Šumava se má opèt otevř́t turistùm, rozhodl soud. [online] URL: 〈http://www.novinky. cz/domaci/219798-sumava-se-ma-opet-otevritturistum-rozhodl-soud.html $>$ [2011-12-05].

PEREIRA, M. B., FERREIRA, A. C. and ROCHA, L. C., 2012: Trilha Interpretativa Geoturística na Serra de São José no Entorno da Estrada Real / MG. Anuario do Instituto de Geociencias, 35, 1: 165172. ISSN 0101-9759.

PRAH, K. and KOLNIK, K. K., 2007: Didactic analysis of outdoor learning based on the example of the educational water trail in the Sotla river basin. Didactica slovenica-Pedagoška obzorja, 22, 3-4: 38-52. ISSN 0353-1392.

RITCHIE, J. R. B. and CROUCH, G. I., 2003: The competitive destination: A sustainable tourism perspective. 
1st ed. Oxon: CABI Publishing, 272 p. ISBN 0-85199-664-7.

ROGERSON, M. C., 2007: Tourism routes as vehicles for local economic development in South Africa: The example of the Magaliesberg Meander. Urban Forum, 18, 2: 49-68. ISSN 1015-3802.

STREET, D. J., BURGESS, L. and LOUVIERE, J. L., 2005: Quick and easy choice sets: Constructing optimal and nearly optimal stated choice experiments. International Journal of Research in Marketing, 22, 4: 459-470. ISSN 0167-8116.

TOPOLE, M., 2009: Potential for tourism in the demographically threatened region of Jurklošter. Acta Geographica Slovenica, 49, 1: 119-141. ISSN 1581-6613.

VON HIRNSCHALL, F., TOMEK, H., BRANDENBURG, C., REIMOSER, F., LEXER, W., HECKL, F. and ZIENER, K., 2012: Effects of recreation and tourism in large protection areas - spatial and temporal patterns of mountain bikers and their effects on the fauna in the biosphere reserve "wienerwald". Naturschutz und Landschaftsplanung, 44, 11: 341-347. ISSN 09406808.

VYSTOUPIL, J., ŠAUER, M., HOLEŠINSKÁ, A., KUNC, J., SEIDENGLANZ, D., a TONEV, P., 2011: Geografie cestovního ruchu České republiky. Plzeň: Aleš Čeněk, 318 s. ISBN 978-80-7380-340-7.

WEAVER, D., 2006: Sustainable tourism. 1st ed. London and New York: Routledge, 240 p. ISBN 978-0-7506-6438-7.

ZGŁOBICKI, W., KOTODYŃSKA-GAVVRYSIAK, R., GAWRYSIAK, Ł. and PAWŁOWSKI, A., 2012: Walory geoturystyczne rzeźby lessowej zachodniej części Wyżyny Lubelskiej. Przeglad Geologiczny, 60, 1: 26-31. ISSN 0033-2151

RNDr. Josef Navrátil, Ph.D., Department of Economics, Ing. Kamil Pícha, Ph.D., Department of Trade and Tourism, Faculty of Economics, University of South Bohemia in České Budějovice, Studentská 13, 37005 České Budějovice, Czech Republic, e-mail: josefnav@gmail.com, kpicha@ef.jcu.cz 